\title{
Recolonization and cues for bacterial migration into 'mock' deposit-feeder fecal casts
}

\author{
Craig J. Plante ${ }^{1, *}$, Stephanie Stinson ${ }^{2}$ \\ ${ }^{1}$ Grice Marine Laboratory, Department of Biology, University of Charleston, 205 Fort Johnson, Charleston, \\ South Carolina 29412, USA \\ ${ }^{2}$ Newberry College, Newberry, South Carolina 29108, USA
}

\begin{abstract}
Despite the importance of sedimentary bacteria to the cycling of organic matter in the marine environment, fundamental knowledge concerning the determinants of community structure is lacking. Roles of equilibrium processes, such as predation and competition, have generally been found to be of little importance, whereas the role of disturbance in structuring microbial communities has been less explored. Disturbance associated with invertebrate ingestion can reduce bacterial biomass and alter metabolic activities and compositions of bacterial assemblages in marine sediments. The first objective of the research presented here was to determine the mechanisms by which bacterial assemblages recover following their ingestion by deposit feeders. In exposed intertidal sediments, microbial recovery could occur due to regrowth of bacterial populations surviving gut passage, or to migration from adjacent sediments. We used field manipulative experiments to exclude either regrowth, with the use of bacteria-free 'mock' fecal coils, or migration, by isolating coils from surrounding sediments on polystyrene 'latrines.' A second goal was to test whether components of deposit-feeder egesta served as cues for bacterial colonization. Supernatant fluids from the egesta of 4 deposit-feeding species were added to the artificial fecal coils. We then followed the numerical recovery of active and total bacteria in coils through time using CTC (5-cyano-2,3ditoyl tetrazolium chloride) and DAPI stains coupled with epifluorescence microscopy. Our findings indicate that (1) recovery was dominated by immigration, as no recolonization was observed in coils isolated from adjacent sediments, (2) components of 2 of the 4 deposit-feeding species' egesta inhibited bacterial recolonization, and (3) although recovery was observed in coils with added fecal components of the remaining 2 species, in no case was recolonization stimulated relative to seawater addition. The last finding suggests that nutritional provision is not a significant impetus for recolonization of sediment patches disturbed by deposit feeding. Competitor-free space and vertical migrations of diatoms in intertidal sediments are discussed as alternative cues for bacterial recolonization of these disturbed patches.
\end{abstract}

KEY WORDS: Sedimentary bacteria $\cdot$ Deposit feeder $\cdot$ Disturbance $\cdot$ Microbial recolonization

\section{INTRODUCTION}

Sedimentary bacteria are important in the functioning of benthic ecosystems, in that they are the primary remineralizers of organic matter. Deposit feeders are typically the dominant macrofaunal guild in soft sediments (Jumars 1993), and ingest bacteria associated with sediments at a high frequency (Thayer 1983, Wheatcroft et al. 1990). Deposit feeders have been shown to affect bacterial densities (e.g. Moriarty et al. 1985, Grossmann \& Reichardt 1991), growth (e.g. Deming \& Colwell 1982, Plante et al. 1989), activity (Juniper 1981, Deming \& Colwell 1982, Aller \& Yingst 1985), and impact community compositions (e.g. Dobbs \& Guckert 1988, Duchene et al. 1988, WardRainey et al. 1996).

Historically, the relationship between deposit feeders and sedimentary bacteria has been studied in the 
context of a classic predator-prey $(+,-)$ interaction. We argue here that treatment of deposit-feeder ingestion as a disturbance is more appropriate. Most importantly, it is not clear that digestion of bacteria provides a net gain to deposit feeders (e.g. Lopez \& Levinton 1987, Kemp 1990). When compared to the typical relationship of a predator and prey, the effect of a deposit feeder on ingested microbes occurs over larger spatial scales, influences communities as opposed to individuals, and is less selective. Moreover, a disturbance disrupts the physical environment as well as biota. Deposit feeding alters geochemical gradients within ingested sediments (Aller 1982, Plante \& Jumars 1992), dramatically affects the quantity and architecture of microbial biofilms (Decho \& Lopez 1993), and can affect grain size, sorting, water content and compaction of sediments (Gray 1974, Rhoads \& Boyer 1982).

The apparent lack of regulating effects of competition (DeFlaun \& Mayer 1983, Schmidt et al. 1998) and predation (by macrofauna: Bianchi \& Levinton 1981, Kemp 1987, 1990; meiofauna: Kemp 1990, Epstein \& Shiaris 1992; and protozoa: Kemp 1988, Epstein \& Shiaris 1992, Epstein 1997), coupled with the high diversity (e.g. Piceno et al. 1999, Scala \& Kerkhof 2000) and low stability (Findlay et al. 1990a,b, Rooney-Varga et al. 1997) of microbial communities in sediments suggests an important role for non-equilibrium determinants of community structure. Non-equilibrium models emphasize environmental disturbance and spatial heterogeneity in habitats in which a state of equilibrium is unusual (Reice 1994). Community structure in this case is largely determined by the interactions of the heterogeneity of the physical-chemical environment, disturbance and recolonization (Hutchinson 1961, Sousa 1984).

There are 3 mechanisms by which a species can recolonize newly available space after disturbance: regrowth, migration and recruitment (Reice 1994). In the case of bacteria in invertebrate egesta, regrowth refers to repopulation by survivors of gut passage, migration refers to those bacteria colonizing egesta from adjacent sediment, and recruitment to colonization from air (emersed egesta) or overlying water (immersed egesta).

In previous experiments, by isolating fresh egesta of 2 deposit-feeding species from underlying intertidal sediments with 'latrines' (see description and Fig. 1 in Plante \& Wilde 2001), we tentatively rejected the null hypothesis that migration was an unimportant mechanism in recoloniziation (Plante \& Wilde 2001).

Here we report on complementary experiments, which employed artificial fecal coils to eliminate the potential for microbial regrowth in egesta, to also test the hypothesis that bacterial regrowth is a significant mode of recolonization of biotically disturbed sediments. An additional benefit of these artificial fecal coils was the reduction of a signal-to-noise problem due to the high variability in bacterial densities inherent in natural fecal matter. A second goal was to test the hypothesis that deposit-feeder egesta serve as cues for bacterial migration in sediments.

\section{MATERIALS AND METHODS}

Site and species. Sediment samples were collected from, and experiments were performed at, Breach Inlet $\left(32^{\circ} 46^{\prime} 23^{\prime \prime} \mathrm{N}, 79^{\circ} 48^{\prime} 53^{\prime \prime} \mathrm{W}\right)$, a protected sandy beach on the north end of Sullivans Island, South Carolina, USA. From this same site, fecal materials ( $<1 \mathrm{~h}$ old) were collected from 3 deposit feeders: Nereis succinea (Polychaeta: Nereidae), Balanoglossus aurantiacus (Enteropneusta: Ptychoderidae), and Leptosynapta tenuis (Holothuroidea: Synaptidae). In addition, fecal materials from Arenicola cristata (Polychaeta: Arenicolidae) were collected from Huntington Beach State

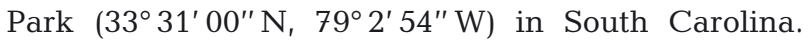
Fecal materials were stored at $-20^{\circ} \mathrm{C}$ prior to use.

Experimental treatments. Field manipulative experiments, employing $\mathrm{H}_{2} \mathrm{O}_{2}$-boiled sediment, were used to determine the role of regrowth in the recolonization of egesta. After boiling for $10 \mathrm{~min}$ in 10 volumes of $30 \%$ peroxide, sediments were vacuum-filtered $(0.2 \mu \mathrm{m}$ bottle-top filter) to remove peroxide and washed with 40 volumes of sterile, filtered $(0.2 \mu \mathrm{m})$ seawater. Following complete removal of the seawater wash, 0.5 volumes more of sterile filtered seawater were added to the dried sediments for re-saturation. A 1 cc syringe (Luer end cut off) was used to extrude 'mock' fecal coils, with the potential for bacterial regrowth removed, that were similar in size and shape to fecal coils of Balanoglossus aurantiacus. These artificial fecal coils were placed onto surficial sediments at Breach Inlet, in an area that included B. aurantiacus, Leptosynapta tenuis and Nereis succinea. A second type of treatment employed both mock fecal coils and latrines (potential for regrowth and migration excluded). Latrines were identical to those employed by Plante \& Wilde (2001). An additional control consisted of ambient sediments filtered, washed, resaturated with seawater, and extruded as described above, but without the initial peroxide boiling (Table 1).

To test whether the components of the egesta of deposit feeders act as cues for bacterial migrations, we prepared mock fecal coils like those described above, but we used the supernates from centrifuged egesta of the 4 invertebrate species to re-saturate the sediment (see Table 1). Egesta were centrifuged at $4000 \times g$ for $15 \mathrm{~min}$ at $15^{\circ} \mathrm{C}$. Supernates were removed via pipet, 
pooled, then filtered $(0.2 \mu \mathrm{m})$ to remove bacteria and other particulates prior to addition to bacteria-free sediments.

Experimental units of the various treatments $(\mathrm{N}=8$ per treatment) were haphazardly interspersed on the beach at the mid-level of Balanoglossus aurantiacus distribution ( $\sim 0.5 \mathrm{~m}$ tidal level), with each artificial coil located a minimum of $0.5 \mathrm{~m}$ from extant fecal coils or mounds. Duration of experiments ( 2 to $3 \mathrm{~h}$ ) spanned nearly the entire period of tidal exposure at the chosen site, from ebb tide through just prior to immersion during flood tide. Both the 2000 and 2001 experiments were conducted on clear, warm (always $>25^{\circ} \mathrm{C}$ ) days, from late morning into early afternoon. All treatments and control areas were covered with $5.5 \times 11.5 \mathrm{~cm}$ (height $\times$ diameter) cylindrical glass-culture dishes to inhibit evaporation. Preliminary tests showed that fecal casts on latrines lost significantly more water relative to naturally incubated egesta ( $7.8 \mathrm{vs} 2.6 \% \mathrm{~h}^{-1}$, $\mathrm{p}=0.001$ ); however, with the glass covering, water loss was not significantly different than that of unmanipulated B. aurantiacus fecal casts $(p=0.776)$.

In 2001, ambient sediments were also sampled from the Breach Inlet field site for enumeration of total bacteria. In addition, ambient sediment, $\mathrm{H}_{2} \mathrm{O}_{2}$-treated sediment, and fecal samples were taken for \% organic matter $(\mathrm{OM})$ determination via combustion at $550^{\circ} \mathrm{C}$.

Data analysis. Each treatment was sampled (by spatula) through time (e.g. 0, 1, and 2+ h) for enumeration of total and active bacterial numbers, via DAPI and CTC staining, and epifluorescence microscopy. Care was taken to avoid underlying ambient sediment so that the bottom $\sim 1 \mathrm{~mm}$ of cylindrical coils were left unsampled. All sediment, fecal or gut samples taken for enumeration were placed in sterile $50 \mathrm{ml}$ centrifuge

Table 1. Summary of experimental treatments. Mock fecal coils refer to peroxide-boiled and rinsed Breach Inlet sediments, extruded onto beach using cut-off 1 cc syringe

\begin{tabular}{|ll|}
\hline $\begin{array}{l}\text { Treatment } \\
\text { designation }\end{array}$ & \multicolumn{1}{c|}{ Description } \\
\hline July 2000 & \\
MF & Mock fecal coil + seawater \\
LMF & Mock fecal coil + seawater, on latrine \\
BA & Mock fecal coil + Balanoglossus aurantiacus egesta supernate \\
NS & Mock fecal coil + Nereis succinea egesta supernate \\
C & Rinsed, natural sediments (washed, dried, and re-saturated \\
& like MF, but not peroxide-treated) \\
July 2001 & \\
MF & Mock fecal coil + seawater \\
LMF & Mock fecal coil + seawater, on latrine \\
LT & Mock fecal coil + Leptosynapta tenuis egesta supernate \\
AC & Mock fecal coil + Arenicola cristata egesta supernate \\
\hline
\end{tabular}

tubes containing $20 \mathrm{ml}$ of filtered $(0.2 \mu \mathrm{m})$, sterile seawater, and held on ice until return to the laboratory $(<1 \mathrm{~h}$ after final sampling). Bacteria were dislodged from the sediment using a short burst (20 s) of sonication with a $3 \mathrm{~mm}$ sonic probe (amplitude $=306 \mu \mathrm{m}$, power output $=65 \mathrm{~W}$ ). Sonication time and intensity were selected based on previous optimization studies (Wilde \& Plante 2002).

Aliquots $(2 \mathrm{ml})$ were taken from the diluted, sonicated samples and transferred to $15 \mathrm{ml}$ centrifuge tubes for the CTC reduction assay. CTC $(200 \mu \mathrm{l}$ of $25 \mathrm{mM}$ ) was added to each tube and incubated $(4 \mathrm{~h})$ at $28^{\circ} \mathrm{C}$ in the dark while shaking ( 200 rpm). Duplicate aliquots $(1 \mathrm{ml})$ from this incubation were fixed in formalin ( $4 \%$ final concentration) for direct counts of active and total bacteria.

Total counts were made with DAPI using a modified version of the protocol of Hymel \& Plante (1998). Briefly, fixed samples were centrifuged at $4000 \times g$ for 15 min then resuspended in Trizma buffer $(0.05 \mathrm{M}, \mathrm{pH}$ $8.10)$ and a dispersing agent (0.5\% Triton-X 100) and sonicated for $20 \mathrm{~s}$ with a $3 \mathrm{~mm}$ sonic probe at $65 \mathrm{~W}$. Samples were then stained with DAPI (10 ppm final concentration) for $20 \mathrm{~min}$, re-centrifuged to remove the stain, and concentrated onto $0.2 \mu \mathrm{m}$ pore size black polycarbonate membranes (Poretics).

Both total and active counts were made from each slide using a Nikon epifluorescence microscope at 1250×. DAPI-stained bacteria were counted using a UV filter set (Omega XFO2, 330WB80 exciter, 400EFLP emitter). Active bacteria (CTC staining) were counted using a rhodamine filter set (Omega 605DF55, center wavelength $=605 \mathrm{~nm}$, discriminating filter, full band width at $1 / 2$ maximum transmission $=55 \mathrm{~nm}$ ). For each sample and filter set, 20 grids (or more) were counted to include $>200$ cells per slide. Values for blanks (filtered, sterile seawater) were subtracted for each measurement. Total counts were calculated from the sum of DAPI-stained and CTC-stained cells because of interference of fluorescence emission of DAPI-stained cells by CTC (Yu et al. 1995). Samples were then dried and weighed, and counts were expressed as cells $g$ dry sediment $^{-1}$.

Two-way ANOVA was used to test for effects of time and treatment. If the main effects were significant, post-hoc multiple comparison tests were performed using Fisher's LSD correction. If the main effects were not significant, the more conservative Bonferroni's correction was used for multiple comparisons (Milliken \& Johnson 1984). 


\section{RESULTS}

The $\mathrm{H}_{2} \mathrm{O}_{2}$ treatment was successful in that bacteria were effectively removed (95 and 92\% removal in 2000 and 2001, respectively) from sediment. Simply washing, drying and resaturating the sediments (our ' $\mathrm{C}$ ' treatment; see Table 1 for all treatment definitions ) also resulted in the loss of both active and total bacteria $(\sim 55 \%)$ relative to ambient values (mean $=2.6 \pm 0.3$ [SE] $\times 10^{8}$ bacteria g dry sediment ${ }^{-1}$ in unmanipulated sediments, $\mathrm{N}=3$ ), albeit not nearly as efficiently as with peroxide (Fig. 1). Organic matter was also sub-
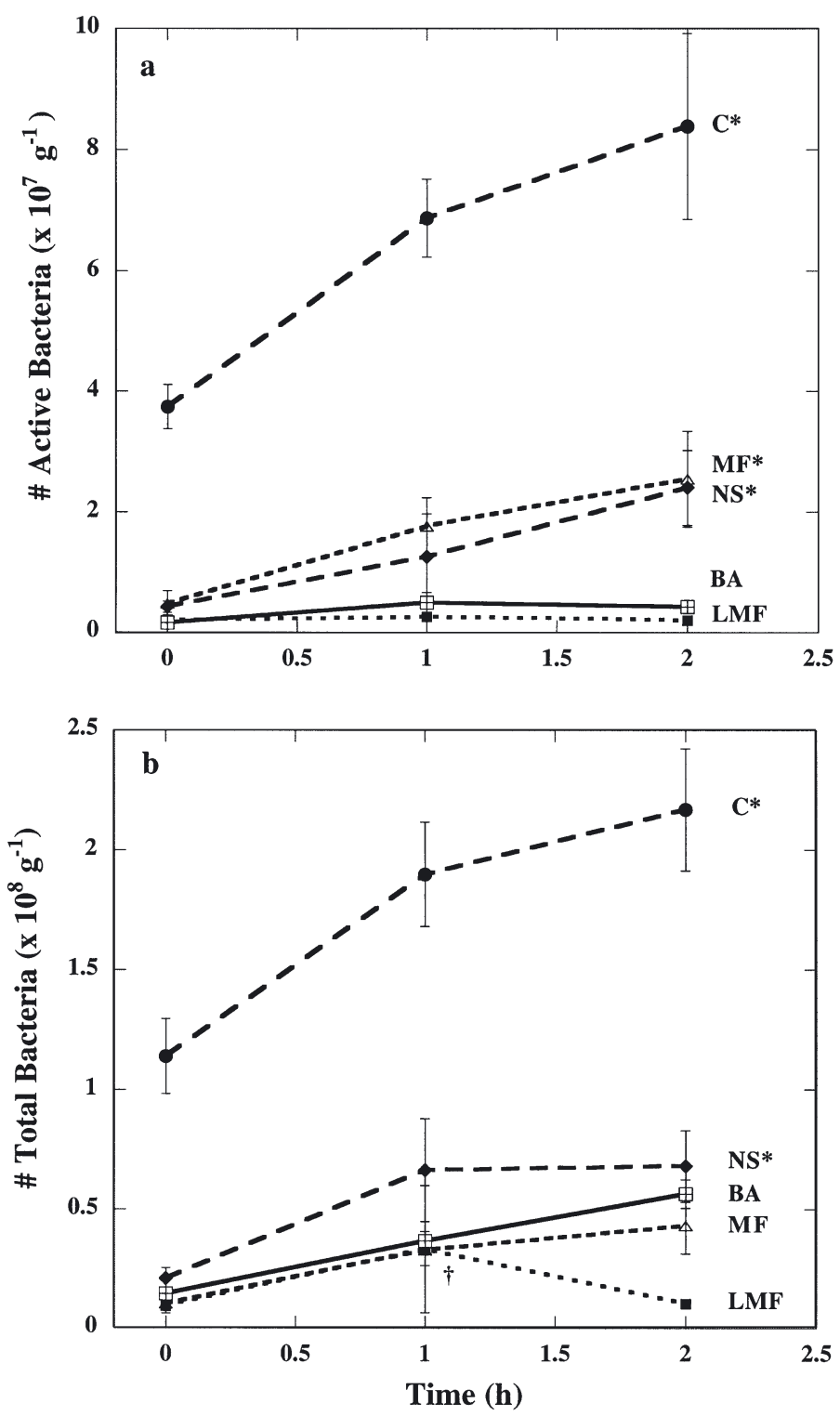

Fig. 1. Mean $\pm 1 \mathrm{SE}$ of (a) active, and (b) total bacteria through time (July 2000 experiments). See Table 1 for definitions of all abbreviations. *: significant temporal change; $\dagger$ : 1 extreme outlying value was removed from analysis (LMF treatment at $1 \mathrm{~h}$ ) stantially reduced by $\mathrm{H}_{2} \mathrm{O}_{2}$ treatment, from $0.93(\mathrm{~N}=4)$ to $0.43 \%(\mathrm{~N}=3)$.

\section{July 2000 experiments}

In 2000, active bacterial numbers showed significant treatment $(p<0.001)$, time $(p<0.001)$, and treatment $x$ time interaction effects $(\mathrm{p}=0.037)$. At $t=0 \mathrm{~h}$, the $\mathrm{C}$ treatment varied significantly from all other treatments $(p<0.002)$, whereas there were no other significant differences among the 4 other treatments ( $p>0.700$ for all other treatment versus treatment comparisons) (Fig. 1a). After 2 h, LMF was significantly different than the MF ( $p=0.009)$ and NS ( $p=0.014)$ treatments, and the BA samples also had significantly fewer active bacteria than did MF ( $p=0.011$ ) and NS ( $p=0.017$ ) treatments. BA and LMF did not differ significantly $(p=0.797)$, nor did the MF and NS treatments vary from one another $(\mathrm{p}=0.864)$, at $t=2$ $\mathrm{h}$ (Fig. 1a). No increase in active bacteria through time was seen in the LMF treatment (Fig. 1a; p = 0.991), whereas numbers did increase approximately $4 \times$ in the MF treatment from 0 to $2 \mathrm{~h}$ (Fig. $1 \mathrm{a} ; \mathrm{p}=$ 0.028). C and NS treatments likewise experienced significant increases in numbers of active bacteria between 0 and $2 \mathrm{~h}(\mathrm{p}<0.001$ and $\mathrm{p}=0.021$, respectively; Fig 1a).

Treatment $(\mathrm{p}<0.001)$, time $(\mathrm{p}<0.001)$ and the treatment $\times$ time interaction $(p=0.004)$ all had a significant effect on total bacterial numbers. Although total numbers were dominated by DAPI counts (active bacterial counts averaged $24.4 \%$ of total counts), patterns were generally similar to those of active bacterial numbers. At $t=0 \mathrm{~h}$, treatments were not different from one another (Fig. 1b; $p>0.713$ for all pair-wise comparisons, except with the control, C). After $2 \mathrm{~h}, \mathrm{LMF}$ was significantly different than the NS ( $p=0.004)$ and BA $(p=0.041)$ treatments, and trended toward a significant difference against $\mathrm{MF}$ ( $p=0.093$ ) (Fig. 1b). Between 0 and 2 h, a numerical increase was observed in the NS samples (Fig. $1 \mathrm{~b} ; \mathrm{p}$ $=0.028)$, but no significant change was noted for LMF (Fig. 1b; $\mathrm{p}=0.960$ ). MF and BA appeared to increase to a lesser degree (Fig. 1b), but these temporal changes were not significant $(\mathrm{p}=0.092$ and 0.080 for MF and BA, respectively) at $\alpha=0.05$.

In addition, numerical increases in active and total bacteria were noted in the control (Fig. 1; p $<0.001$ for both), which was incubated in contact with beach sediment. Recovery was nearly complete after $2 \mathrm{~h}$ in the control treatment when compared to ambient values $\left(\right.$ mean $=2.6 \times 10^{8} \mathrm{~g}_{\text {dry }}$ sediment $^{-1}$ ); recovery in no other treatment approached ambient bacterial densities over this incubation time (Fig. 1). 


\section{July 2001 experiments}

In the July 2001 experiments, active bacterial numbers showed a significant treatment effect $(\mathrm{p}=$ $0.026)$, with LMF differing from both MF $(p=0.007)$ and LT $(\mathrm{p}=0.013)$ treatments, but not from AC $(\mathrm{p}=$ $0.210)$. Time also had a significant effect $(p<0.001)$, between both 0 and $3 \mathrm{~h}(\mathrm{p}<0.001)$ and 1 and $3 \mathrm{~h}(\mathrm{p}<$ 0.001 ). Treatment $\times$ time interaction effects were not significant $(p=0.561)$. No temporal increase in active bacteria was seen in the LMF or AC treatments (Fig. $2 \mathrm{a} ; \mathrm{p}=1.000$ and $\mathrm{p}=0.121$ for 0 vs $3 \mathrm{~h}$ comparisons, respectively), whereas numbers increased significantly in the MF ( $p=0.008$ for 1 vs $3 h$ ) and LT treatments (Fig. 2a; $\mathrm{p}=0.005$ between 0 and $3 \mathrm{~h}$ ).

Treatment $(p<0.001)$ and time $(p=0.049)$ had a significant effect on total bacterial numbers; however, the interaction was not significant $(p=0.273)$. The LMF treatment varied significantly from both the MF $(p<$ $0.001)$ and LT $(p<0.001)$ treatments, and these 2 also differed significantly from the AC treatment $(p<0.001$ and $p=0.016$ for MF and LT, respectively) (Fig. 2b).

Between 0 and $2.5 \mathrm{~h}$, no significant changes were observed in any treatment. Using the less conservative LSD correction, a weak numerical increase was observed in the MF samples $(p=0.029)$, whereas no significant change was seen for the LMF ( $p=0.788)$, LT $(\mathrm{p}=0.130)$, or $\mathrm{AC}(\mathrm{p}=0.834)$ treatments (Fig. $2 b)$.

\section{DISCUSSION}

Immigration plays a primary role in the recolonization of disturbed intertidal sediments. In neither experiment was recovery observed when mock coils were isolated on latrines (i.e. recovery in MF > LMF). As expected, this pattern was especially apparent with counts of CTC-stained active bacteria, as migrating (or dividing) cells would normally be metabolically active. The lack of recovery in the LMF treatment does not, however, exclude the possibility that regrowth plays some role in recolonization in situ, as the potential exists that our $\mathrm{H}_{2} \mathrm{O}_{2}$ treatment negatively influenced growth of the remaining bacteria in mock casts, or of new immigrants. This would seem unlikely, however, as the sediments were washed with 40 volumes of sterile seawater following $\mathrm{H}_{2} \mathrm{O}_{2}$ treatment, and migration did not appear to be inhibited.

These results complement and corroborate earlier findings (Plante \& Wilde 2001), which indicate that microbial recolonization of disturbed sediments is primarily via immigration. These earlier findings with actual deposit-feeder fecal coils employed enumeration of bacteria plus metabolic profiles (i.e. Biolog plates). In that study, metabolic fingerprints in latrine- isolated egesta remained static and statistically distinct from those of sediments over time, whereas fingerprints of naturally incubated feces diverged from those on the latrines and came to more closely resemble profiles of sedimentary bacterial assemblages. The experiments reported here were designed to complement the earlier study, in that the possibility of regrowth was removed, in addition to excluding migration. The artificial coils used here, in those treatments not including deposit-feeder gut fluids (i.e. MF, LMF, and C), also eliminated a source of potential confusion. It is possible, but not yet demonstrated, that bacteriolysis by digestive secretions could continue within the egesta of deposit feeders. Although both digestive enzymes
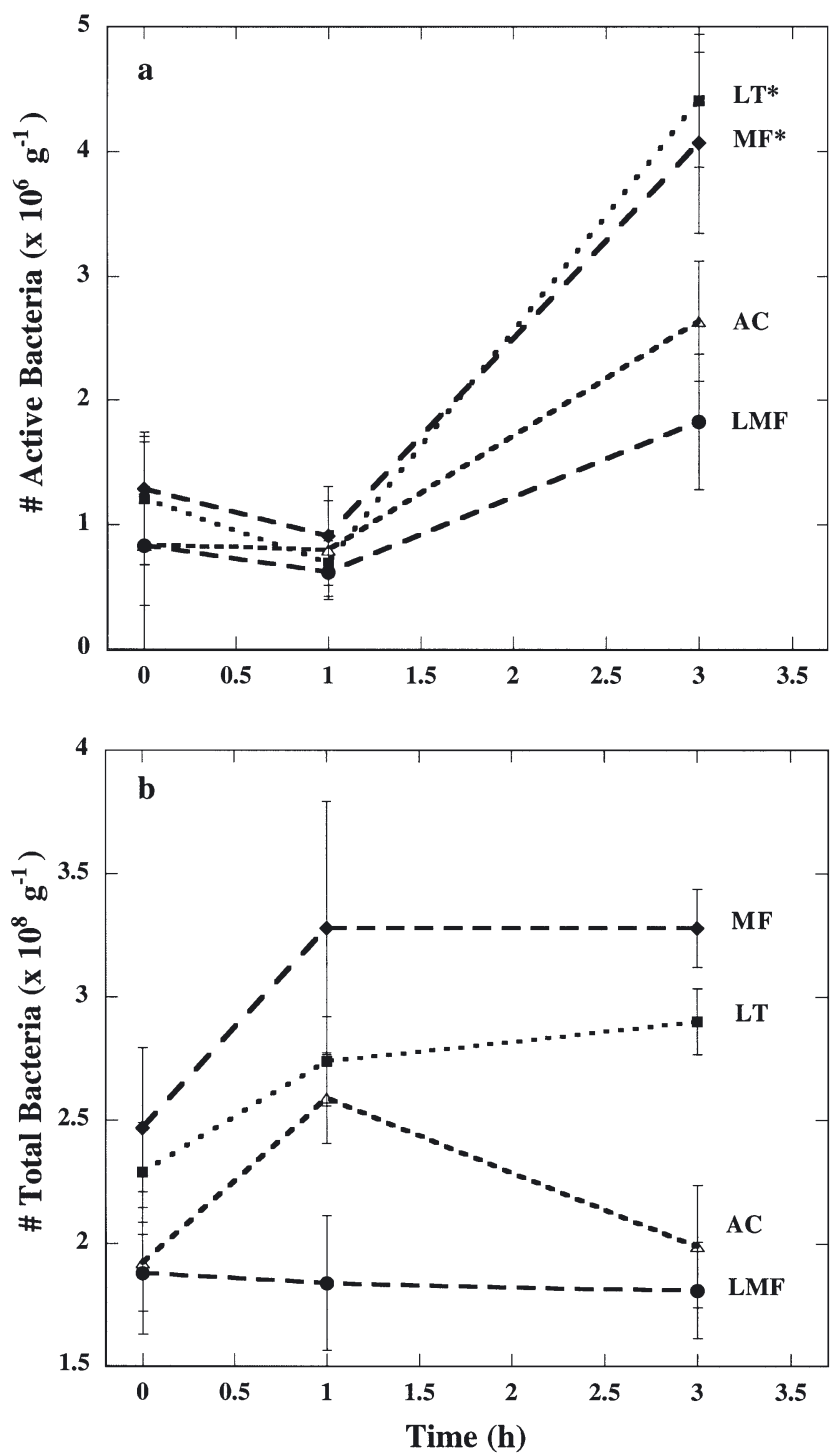

Fig. 2. Mean \pm 1 SE of (a) active, and (b) total bacteria through time (July 2001 experiments). See Table 1 for definitions of all abbreviations. *: significant temporal change 
and surfactants have been detected in gut segments posterior to areas of active digestion and absorption (Plante \& Mayer 1994, Mayer et al. 1997), lytic activities in fecal materials have not directly been demonstrated. That we observed similar rates of recovery, regardless of whether mock coils were saturated with seawater or the fluids of Nereis succinea and Leptosynapta tenuis, indicates that at least in these 2 species, net recovery is not significantly influenced by lysis within the egesta.

The recovery in mock coils plus Nereis succinea and Leptosynapta tenuis supernates was not different than that in mock coils plus seawater $(\mathrm{NS}=\mathrm{MF}$ and $\mathrm{LT}=$ MF). Recovery with Balanoglossus aurantiacus and Arenicola cristata supernates was inhibited (MF $>$ AC, $\mathrm{BA}$ and $\mathrm{LMF}=\mathrm{AC}$ and $\mathrm{BA})$. In no case did components from deposit-feeder egesta accelerate recovery relative to seawater-saturated coils. This result was somewhat unexpected, as accepted theories suggest that some fraction of digestive products should be lost to the egesta (Dade et al. 1990, Plante et al. 1990), and rapid bacterial growth in the hindgut (Deming \& Colwell 1982, Plante et al. 1989) and elevated metabolic activities in the feces of deposit feeders (Juniper 1981, Plante \& Jumars 1992) have previously been reported. However, such rapid rates of bacterial growth in deposit-feeder guts and egesta have not always been observed (e.g. Grossmann \& Reichardt 1991, Lucas \& Bertru 1997), and have not been examined in any of the 3 invertebrate species studied here. Although we did not detect significant growth in the fecal matter in previous recolonization experiments (Plante \& Wilde 2001), we did suspect that substances in the egesta might provide a positive chemotactic cue for motile bacteria.

Substances within the feces of Balanoglossus aurantiacus and Arenicola cristata inhibited immigration. Our previous study, which examined recolonization of natural fecal matter of Nereis succinea and B. aurantiacus using epifluorescence microscopy and Biolog plates, also suggested that recovery in B. aurantiacus egesta was inhibited relative to $N$. succinea egesta (Plante \& Wilde 2001). Both B. aurantiacus and A. cristata produce haloaromatic metabolites (Woddin et al. 1987), whereas $N$. succinea and Leptosynapta tenuis are not known to do so. Many studies have explored the potential roles of these compounds in deterring predation (Prezant et al. 1981, Woodin et al. 1987, Pawlik 1993), excluding competitors (Pawlik 1992, Woodin et al. 1993), and inhibiting microbial activity (King 1986, Goerke \& Weber 1991). However, concentrations of these compounds in fecal materials are low and unlikely to inhibit bacteria (King 1986). Moreover, the notion that halogenated secondary metabolites are generally inhibitory to sedimentary bacteria has, at times, been contradicted (Steward et al. 1992, Lovell et al. 1999).

The metabolic by-products of anaerobic metabolism in deep, anoxic sediments might instead be involved. Balanoglossus aurantiacus and Arenicola cristata are by far the largest of the 4 species studied here, burrowing to, and feeding at, the greatest depths. It is probable that $B$. aurantiacus actually ingests deeper, anoxic sediments. Although the studies of Duncan (1987) suggest that surficial sediments are subducted to depths of 3 to $10 \mathrm{~cm}$ to be ingested by $B$. aurantiacus, he also demonstrated that these deposit feeders shift the positions of their burrows and feeding funnels daily. Thus, anoxic sediments are likely ingested both when the animal relocates and, to a lesser degree, in normal feeding modes. At our study site, at least a fraction ( $20 \%$; Wilde \& Plante 2002) of fresh B. aurantiacus coils are gray or black in color, and almost certainly were reducing (low or negative Eh) when ingested. $A$. cristata likewise inhabits deep (>30 cm for adults, C. J. Plante pers. obs.), U-shaped borrows and feeds in a similar manner (Ruppert \& Fox 1988). Plante \& Jumars (1992) demonstrated that the gut contents of the closely related lugworm A. pacifica are anaerobic. Low oxygen levels and elevated ammonium concentrations, for instance, have been shown to be inhibitory to the recruitment of benthic animal larvae (Woodin et al. 1998, Marinelli \& Woodin 2002) and presumably could be inhibitory to growth and/or metabolism of aerobic bacteria. Other potential chemical deterrents associated with deep, anoxic sediments include sulfides and various dissolved organic compounds (Dubilier 1988, Woodin et al. 1998).

In the absence of these uncharacterized deterrents, bacterial migration into disturbed marine sediments must be an active process. Passive mechanisms, which could result in increasing bacterial numbers in 'bacteria-free' sediments in contact with ambient sediments, include Brownian rotational diffusion (Jackson 1987) and bulk movement of porewaters. However, neither of these processes would be influenced by the presence or absence of cues, as was noted here for mock coils saturated with fecal supernates of Balanoglossus aurantiacus and Arenicola cristata.

As the concentration of $\mathrm{OM}$ in mock coils was reduced relative to ambient sediment (by approximately $54 \%$ ), it is unlikely that substrate-mediated chemokinesis led to colonization. One incentive for the active migration into mock coils (MF, LT or NS treatments) could be 'competitor-free' space. Organismal migration typically results from crowding (Reice 1994). One plausible explanation for the relatively constant densities of bacteria observed in sediments $\left(\sim 10^{9}\right.$ bacteria $\mathrm{cm}^{-3}$ fluid volume; Schmidt et al. 1998) is that of 'bottom-up' control. Although bacteria attached to 
sediment grains typically occupy a small fraction of available space, theoretical 'spheres of diffusional influence', or the volume in which a bacterium's uptake of a substance affects surrounding concentrations, do correspond with these typical bacterial abundances in marine sediments (Schmidt et al. 1998, Vetter et al. 1998).

How bacteria might sense bacteria-free space and respond over appropriate time spans are questions open for debate. Quorum sensing, or autoinduction, refers to a density-dependent mode of bacteriabacteria communication (typically using akyl homoserine lactones [AHLs] as the diffusible signals). Schmidt et al. (1998) have suggested that quorum sensing might account for self-limitation of cell numbers in sediments by induction of stationary-phase growth. Presumably, AHL gradients could also be sensed and influence migration toward low AHL concentrations. To date, autoinducer activity has been found in freshwater benthic systems (McLean et al. 1997), and AHL-producing bacteria have been isolated from marine snow (Gram et al. 2002) and marine intertidal sediments (J. Easley \& C. J. Plante unpubl. data).

As we took care not to sample into underlying sediments when mock coils were sampled, responding bacteria would have to move well beyond this coilsediment interface $(\sim 1 \mathrm{~mm})$ to be enumerated. Bacterial swimming speeds $\left(>50 \mu \mathrm{m} \mathrm{s}^{-1}\right.$; Vaituzis \& Doetsch 1969, Mitchell et al. 1995) certainly would not preclude this, as they could easily alter their positions by many $\mathrm{mm}$ during the time spans in question. However, numerous previous studies have indicated that the majority of sedimentary bacteria are physically attached to sediment grains in biofilms (Dale 1974, Weise \& Rheinheimer 1978, DeFlaun \& Mayer 1983). Migration must then occur among unattached porewater bacteria, or attachment must be reversible over short (minutes to hours) time scales. Given the levels of recovery noted in this study, coupled with the low densities of free-living bacteria generally observed in porewaters (although uncharacterized at our test site), porewater bacteria are an unlikely source of colonists. Alternatively, there is evidence that particle-attached bacteria could contribute to recovery; Leff et al. (1998) and Kiørboe et al. (2002) have demonstrated rapid attachment and detachment of bacteria in freshwater sediments and marine aggregates, respectively. A potentially more important constraint on attached bacteria is the diffusional impedence associated with biofilms (Decho 1990, deBeer et al. 1994), which would delay the detection of signal molecules to an unknown degree.

As an alternative to chemokinesis directly associated with the presence (or absence) of diffusible com- pounds in the mock coils, sedimentary bacteria might incidentally move (actively) into these coils. For instance, bacteria might naturally migrate vertically in intertidal sediments, as do benthic diatoms (Palmer \& Round 1967, Admiraal et al. 1982, Pinckney et al. 1994). It is largely accepted that microalgae are 'leaky' and provide chemosensory cues and substantial nutritional resources for planktonic bacteria (Azam \& Ammerman 1984, Jackson 1989, Jumars et al. 1989). We know of no published work that has examined this potential relationship in sediments. Alternatively, abiotic stimuli, such as $\mathrm{O}_{2}$ or light, may be more directly involved as they can induce chemokinesis in bacteria (Pandey \& Jain 2002) as well as in benthic microalgae.

One important implication of the finding that migration dominates recolonization is that the sedimentary resource for deposit-feeding invertebrates should be renewed more rapidly than would be expected through repopulation by survivors of ingestion. Bacteria can swim faster than they can grow and divide, and-in the case of in situ growth-digestionresistant taxa (Duchene et al. 1988, Plante \& Shriver 1998) would likely come to dominate fecal casts and sediments.

Non-equilibrium theories attribute high diversity and the coexistence of similar species to processes of disturbance and recruitment. However, because the results of this study indicate that recolonization is primarily through migration from adjacent sediments, we should not observe greater species richness or diversity in egesta relative to sediments - the source for colonists is largely restricted to the bacterial assemblage of those sediments. At the larger landscape scale, however, we might expect higher diversity in areas with deposit-feeder disturbances, relative to undisturbed areas.

That digestive components did not enhance the rate of colonization in mock coils relative to seawater suggests that our main finding regarding recovery mode can be generalized to many other, especially abiotic, types of disturbance in intertidal sediments (e.g. abrasion; Miller 1989). However, if disturbance is dramatic, exposing deeper anoxic sediments, immigration may instead be inhibited. Whether these findings are applicable to subtidal situations awaits testing, and would not be expected to apply in deep waters if, indeed, the migrations observed by us are found to be related to light or vertical migrations of benthic microalgae. Seawater immersion, even in shallow waters, may also enhance other modes of recolonization, including recruitment via seawater (vs air when intertidal sediments are exposed) and the growth rates of bacteria, relative to migration. 
Acknowledgements. Field and laboratory assistance was provided by Me'Chell James and Jeremiah Easley, respectively. Financial support was provided by the National Science Foundation grant DEB 0108615, the Belle W. Baruch Visiting Scholar Program, and the South Carolina DNR Marine Resources Division Minority Summer Intern Program.

\section{LITERATURE CITED}

Admiraal W, Peletier H, Zomer H (1982) Observations and experiments on the population dynamics of epipelic diatoms from an estuarine mudflat. Estuar Coast Shelf Sci 14:471-487

Aller RC (1982) The effects of macrobenthos on chemical properties of marine sediment and overlying water. In: McCall PL, Tevesz MJS (eds) Animal-sediment relations. Plenum Press, New York, p 53-102

Aller RC, Yingst JY (1985) Effects of the marine deposit feeders Heteromastus filiformis (Polychaeta), Macoma balthica (Bivalvia), and Tellina texana (Bivalvia) on averaged sedimentary solute transport, reaction rates, and microbial distributions. J Mar Res 43:615-645

Azam F, Ammerman JW (1984) Cycling of organic matter by bacterioplankton in pelagic marine ecosystems: microenvironmental considerations. In: Fasham MJR (ed) Flows of energy and material in marine ecosystems. NATO Conference, Series 4, Marine Science, Vol 13. Plenum Press, New York, p 345-360

Bianchi TS, Levinton JS (1981) Nutrition and food limitation of deposit feeders: II. Differential effects of Hydrobia totteni and Ilyanassa obsoleta on the microbial community. J Mar Res 39:547-556

Dade WB, Jumars PA, Penry DL (1990) Supply-side optimization: maximizing absorptive rates. In: Hughes RN (ed) Behavioral mechanisms of food selection. SpringerVerlag, London, p 531-556

Dale NG (1974) Bacteria in intertidal sediments: factors related to their distribution. Limnol Oceanogr 19:509-518

deBeer D, Srinivasan R, Stewart PS (1994) Direct measurement of chlorine penetration into biofilms during disinfection. Appl Environ Microbiol 60:4339-4344

Decho AW (1990) Microbial exopolymer secretions in ocean environments: their role(s) in food webs and marine processes. Oceanogr Mar Biol Annu Rev 28:73-153

Decho AW, Lopez GR (1993) Exopolymer microenvironments of microbial flora: multiple and interactive effects on trophic relationships. Limnol Oceanogr 38:1633-1645

DeFlaun MF, Mayer LM (1983) Relationships between bacteria and grain surfaces in intertidal sediments. Limnol Oceanogr 28:873-881

Deming JW, Colwell RR (1982) Barophilic growth of bacteria from intestinal tracts of deep-sea invertebrates. Microb Ecol 7:85-94

Dobbs FC, Guckert JB (1988) Microbial food resources of the macrofaunal-deposit feeder Ptychodera bahamensis (Hemichordata: Enteropneusta). Mar Ecol Prog Ser 45: $127-136$

Dubilier $\mathrm{N}$ (1988) $\mathrm{H}_{2} \mathrm{~S}$ - a settlement cue or a toxic substance for Capitella sp. I larvae? Biol Bull (Woods Hole) 174: 30-38

Duchene JC, Imbaud P, Delille D (1988) Associated bacterial microflora of a subantarctic polychaete worm Thelepus setosus. Arch Hydrobiol 112:221-231

Duncan PB (1987) Burrow structure and burrowing activity of the funnel-feeding enteropneust Balanoglossus aurantiacus in Bogue Sound, North Carolina, USA. PSZN I: Mar
Ecol 8:75-95

Epstein SS (1997) Microbial food webs in marine sediments. I. Trophic interactions and grazing rates in two tidal flat communities. Microb Ecol 34:188-198

Epstein SS, Shiaris MP (1992) The rates of microbenthos- and meiobenthos bacterivory in a temperate muddy tidal-flat community. Appl Environ Microbiol 58:2426-2431

Findlay RH, Trexler MB, Guckert JB, White DC (1990a) Laboratory study of disturbance in marine sediments: response of a microbial community. Mar Ecol Prog Ser 62:121-133

Findlay RH, Trexler MB, White DC (1990b) Response of a benthic microbial community to biotic disturbance. Mar Ecol Prog Ser 62:135-148

Goerke H, Weber K (1991) Bromophenols in Lanice conchilega (Polychaeta, Terebellidae): the influence of sex, weight and season. Bull Mar Sci 48:517-523

Gram L, Grossart HP, Schlingloff A, Kiorbe T (2002) Possible quorum sensing in marine snow bacteria: production of acylated homoserine lactones by Roseobacter strains isolated from marine snow. Appl Environ Microbiol 68: 4111-4116

Gray JS (1974) Animal-sediment relationships. Oceanogr Mar Biol Annu Rev 12:223-261

Grossmann S, Reichardt W (1991) Impact of Arenicola marina on bacteria in intertidal sediments. Mar Ecol Prog Ser 77: 85-93

Hutchinson GE (1961) The paradox of the plankton. Am Nat 95:137-145

Hymel S, Plante C (1998) Improved method of bacterial enumeration in sandy and deposit-feeder gut sediments using the fluorescent stain 4,6-diamidino-2-phenylindole (DAPI). Mar Ecol Prog Ser. 173:299-304

Jackson GA (1987) Simulating chemosensory responses of marine organisms. Limnol Oceanogr 32:1253-1266

Jumars PA (1993) Concepts in biological oceanography. Oxford University Press, New York

Jumars PA, Penry DL, Baross JA, Perry MJ, Frost BW (1989) Closing the microbial loop: dissolved carbon pathway to heterotrophic bacteria from incomplete ingestion, digestion and absorption in animals. Deep-Sea Res 36:483-495

Juniper SK (1981) Stimulation of bacterial activity by a deposit feeder in two New Zealand intertidal inlets. Bull Mar Sci 31:691-701

Kemp PF (1987) Potential impact on bacteria of grazing by a marine deposit feeder, and the fate of bacterial production. Mar Ecol Prog Ser 36:151-161

Kemp PF (1988) Bacterivory by benthic ciliates: significance as a carbon source and impact on sediment bacteria. Mar Ecol Prog Ser 49:163-169

Kemp PF (1990) The fate of benthic bacterial production. Rev Aquat Sci 2:109-124

King GM (1986) Inhibition of microbial activity in marine sediments by a bromophenol from a hemichordate. Nature 323:257-259

Kiørboe T, Grossart H, Ploug H, Tang K (2002) Mechanisms and rates of bacterial colonization of sinking aggregates. Appl Environ Microbiol 68:3996-4006

Leff LG, McArthur JV, Shimkets LJ (1998) Persistence and dissemination of introduced bacteria in freshwater microcosms. Microb Ecol 36:202-211

Lopez GR, Levinton JS (1987) Ecology of deposit-feeding animals in marine sediments. Quart Rev Biol 62:235-259

Lovell CR, Steward CC, Phillips T (1999) Activity of marine sediment bacterial communities exposed to 4-bromophenol, a polychaete secondary metabolite. Mar Ecol Prog Ser 179:241-246

Lucas F, Betru G (1997) Bacteriolysis in the gut of Nereis 
diversicolor (O.F. Muller) and effect of the diet. J Exp Mar Biol Ecol 215:235-245

Marinelli RL, Woodin SA (2002) Experimental evidence for linkages between infaunal recruitment, disturbance, and sediment surface chemistry. Limnol Oceanogr 47:221-229

Mayer LM, Schick LL, Self RFL, Jumars PA, Findlay RH, Chen Z, Sampson S (1997) Digestive environments of benthic macroinvertebrate guts: enzymes, surfactants, and dissolved organic matter. J Mar Res 55:785-812

McLean RJC, Whitely M, Stickler DJ, Fuqua WC (1997) Evidence of autoinducer activity in naturally occurring biofilms. FEMS Microb Ecol Lett 154:259-263

Miller DC (1989) Abrasion effects on microbes in sandy sediments. Mar Ecol Prog Ser 55:73-82

Milliken GA, Johnson DE (1984) Analysis of messy data, Vol I: designed experiments. Van Nostrand Reinhold, New York

Mitchell JG, Pearson L, Dillon S, Kantalis K (1995) Natural assemblages of marine bacteria exhibiting high-speed motility and large accelerations. Appl Environ Microbiol 61:4436-4440

Moriarty DJW, Pollard PC, Hunt WG, Moriarty CM, Wassenberg TJ (1985) Productivity of bacteria and microalgae and the effect of grazing by holothurians in sediments on a coral reef flat. Mar Biol 85:293-300

Palmer J, Round FE (1967) Persistent, vertical-migration rhythms in benthic microflora. VI. The tidal and diurnal nature of the rhythm in the diatom Hantzschia virgata. Biol Bull (Woods Hole) 132:44-55

Pandey G, Jain R K (2002) Bacterial chemotaxis toward environmental pollutants: role in bioremediation. Appl Environ Microbiol 68:5789-5795

Pawlik J (1992) Chemical ecology of the settlement of benthic marine invertebrates. Oceanogr Mar Biol Annu Rev 30: 273-335

Pawlik J (1993) Marine invertebrate chemical defenses. Chem Rev 93:1911-1922

Piceno YM, Noble PA, Lovell CR (1999) Spatial and temporal assessment of diazotroph assemblage composition in vegetated salt marsh sediments using denaturing gradient gel electrophoresis analysis. Microb Ecol 38:157-167

Pinckney J, Piceno Y, Lovell CR (1994) Short-term changes in the vertical distribution of benthic microalgal biomass in intertidal muddy sediments. Diatom Res 9:143-153

Plante CJ, Jumars PA (1992) The microbial environment of marine deposit-feeder guts characterized via microelectrodes. Microb Ecol 23:257-277

Plante CJ, Mayer LM (1994) Distribution and efficiency of bacteriolysis in the gut of Arenicola marina and three additional deposit feeders. Mar Ecol Prog Ser 109:183-194

Plante CJ, Shriver A (1998) Differential lysis of sedimentary bacteria by Arenicola marina: examination of cell wall structure and exopolymeric capsules. J Exp Mar Biol Ecol 229:35-52

Plante CJ, Wilde SB (2001) Bacterial recovery in depositfeeder egesta: in situ growth or immigration? Limnol Oceanogr 46:1171-1181

Plante CJ, Jumars PA, Baross JA (1989) Rapid bacterial growth in the hindgut of a marine deposit feeder. Microb Ecol 18:29-44

Plante CJ, Jumars PA, Baross JA (1990) Digestive associations between marine detritivores and bacteria. Annu Rev Ecol Syst 21:93-127

Prezant YM, Gruber G, Counts CL (1981) Predator repellents of benthic macro-invertebrates. Am Zool 21:1022

Reice SR (1994) Nonequilibrium determinants of biological community structure. Am Sci 82:424-435

Rhoads DC, Boyer LF (1982) The effects of marine benthos on physical properties of sediment: a successional perspective. In: McCall PL, Tevesz MJS (eds) Animal-sediment relations, Vol. 2. The biogenic alteration of sediments. Plenum Press, New York, p 3-52

Rooney-Varga JN, Devereux R, Evans RS, Hines ME (1997) Seasonal changes in the relative abundance of uncultivated sulfate-reducing bacteria in a salt marsh sediment and in the rhizosphere of Spartina alterniflora. Appl Environ Microbiol 63:3895-3901

Ruppert EE, Fox RS (1988) Seashore animals of the Southeast. University of South Carolina Press, Columbia, SC

Scala DJ, Kerkhof LJ (2000) Horizontal heterogeneity of denitrifying bacterial communities in marine sediments by terminal restriction fragment length polymorphism analysis. Appl Environ Microbiol 66:1980-1986

Schmidt JL, Deming JW, Jumars PA, Keil, RG (1998) Constancy of bacterial abundance in surficial marine sediments. Limnol Oceanogr 43:976-982

Sousa WP (1984) The role of disturbance in natural communities. Annu Rev Ecol Syst 15:353-392

Steward CC, Pinckney J, Piceno Y, Lovell CR (1992) Bacterial numbers and activity, microalgal biomass and productivity and meiofaunal distribution in sediments naturally contaminated with biogenic bromophenols. Mar Ecol Prog Ser 90:61-72

Thayer CW (1983) Sediment-mediated biological disturbance and the evolution of marine benthos. In: Tevesz MJS, McCall PL (eds) Biotic interactions in recent and fossil communities. Plenum Press, New York, p 479-625

Vaituzis Z, Doetsch RN (1969) Motility tracks: technique for quantitative study of bacterial movement. Appl Microbiol 17:584-588

Vetter YA, Deming JW, Jumars PA, Krierger-Brockett BB (1998) A predictive model of bacterial foraging by means of freely released extracellular enzymes. Microb Ecol 36: 75-92

Ward-Rainey N, Rainey FA, Stackebrandt E (1996) A study of the bacterial flora associated with Holothuria atra. J Exp Mar Biol Ecol 203:11-26

Weise W, Rheinheimer G (1978) Scanning electron microscopy and epifluorescence investigation of bacterial colonization of marine sand sediments. Microb Ecol 4:175-188

Wheatcroft RA, Jumars PA, Smith CR, Nowell ARM (1990) A mechanistic view of the particulate biodiffusion coefficient: step lengths, rest periods and transport directions. J Mar Res 48:177-207

Wilde SB, Plante CJ (2002) Spatial heterogeneity of microbial assemblages in marine sediments: the influence of deposit feeding by Balanoglossus aurantiacus. Estuar Coast Shelf Sci 55:97-107

Woodin SA, Walla MD, Lincoln DE (1987) Occurrence of brominated compounds in soft-bottom benthic organisms. J Exp Mar Biol Ecol 107:209-217

Woodin SA, Marinelli RL, Lincoln DE (1993) Allelochemical inhibition of recruitment in a sedimentary assemblage. J Chem Ecol 19:517-530

Woodin SA, Marinelli RL, Lindsay SM (1998) Process-specific cues for recruitment in sedimentary environments: geochemical signals? J Mar Res 56:535-558

Yu W, Dodds WK, Banks MK, Skalsky J, Strauss EA (1995) Optimal staining and storage time for direct microscopic enumeration of total and active bacteria in soil with two fluorescent dyes. Appl Environ Microbiol 61:3367-3372 